\title{
The Relationship of Participatory Democracy to Participatory Law Formation
}

Christiana Ochoa

Indiana University Maurer School of Law, cochoa@indiana.edu

Follow this and additional works at: https://www.repository.law.indiana.edu/ijgls

Part of the Civil Law Commons, and the International Law Commons

\section{Recommended Citation}

Ochoa, Christiana (2008) "The Relationship of Participatory Democracy to Participatory Law Formation," Indiana Journal of Global Legal Studies: Vol. 15 : Iss. 1 , Article 2.

Available at: https://www.repository.law.indiana.edu/ijgls/vol15/iss1/2

This Symposium is brought to you for free and open access by the Law School Journals at Digital Repository @ Maurer Law. It has been accepted for inclusion in Indiana Journal of Global Legal Studies by an authorized editor of Digital Repository @ Maurer Law. For more information, please contact rvaughan@indiana.edu.

\section{$\Psi$}

JEROME HALL LAW LIBRARY

INDIANA UNIVERSITY

Maurer School of Law
Blooming ton 


\title{
The Relationship of Participatory Democracy to Participatory Law Formation
}

\author{
Christiana Ochoa*
}

\begin{abstract}
While the traditional doctrinal formulation of customary international law (CIL) has focused exclusively on state practice and opinio juris, in the modern age, it is undeniable that individuals and non-state collectives of individuals are increasingly becoming relevant to this process. It is thus useful to analyze individual participation based on the model of participatory democracy, and also in contrast to representative democracy. By doing so, the nuanced relationship between participatory law formation and democratic participation in lawmaking is brought into relief. In light of larger modern trends within international law, the participation of individuals in law formation requires further examination and theorization to harness and maximize its democratic promise and minimize its potential tendencies toward elitism and secrecy.
\end{abstract}

\section{INTRODUCTION}

The political-philosophical issues addressed in this essay are the result of conceptual questions that arise from my research regarding the participation of individuals in customary international law (CIL) formation. ${ }^{1}$ That ongoing project

* Associate Professor of Law, Indiana University School of Law-Bloomington. J.D., Harvard Law School; B.A., University of Michigan. I would like to thank Fred Aman, Carol Greenhouse, Brian Shoup, Janet Koven-Levit and the participants in the symposium at which this essay was originally presented for their insightful comments. This essay also benefited from the diligent research support provided by Till Müller and the constant support provided by Timothy Lynch. Please send correspondence to the author at cochoa@indiana.edu. My work, including this essay, can be found at http://papers.ssrn.com/sol3/cf_dev/AbsByAuth.cfm?per_id $=439960$.

1. See generally Christiana Ochoa, Towards a Cosmopolitan Vision of International Law: Identifying and Defining CIL Post Sosa v. Alvarez-Machain, 74 U. Cin. L. Rev. 105 (2006) [hereinafter Ochoa, Towards a Cosmopolitan Vision]; Christiana Ochoa, The Individual and Customary International Law Formation, 48 VA. J. INT'L L. 119 (2007) [hereinafter Ochoa, International Law Forma- 
explores the traditional doctrinal formulation of CIL which, at least formally, prescribes that only state practice and opinio juris are to be consulted in the process by which CIL is made. ${ }^{2}$ Briefly stated, this ongoing project asks whether the modern state-centric formulation continues to be coherent today, given the general agreement that individuals have become subjects of international law. ${ }^{3}$ In the course of asking this larger question, I have, among other things, provided doctrinal as well as modern social and philosophical bases for the inclusion of individuals in the CIL formation process. ${ }^{4}$ This research suggests a model that would acknowledge the role individuals play in the CIL formation process and would consult various fonts of information regarding individual belief and expectation with respect to CIL at the moment of its formation. My work on CIL thus proposes a role for individuals within CIL formation doctrine that is much more direct-much more participatory - than CIL doctrine currently provides.

Among the premises that I have relied upon is that there is an intuitive connection between modern theories of participatory democracy and the participation of individuals in CIL formation. In other words, there is a connection between participatory democracy and participatory law formation. Until now, I have left this connection or set of connections largely under-explored. ${ }^{5}$ The objective of this

tion]. Till Müller's contribution to this symposium is closely linked to my prior work on this topic. See Customary Transnational Law: Attacking the Last Resort of State Sovereignty, 15 IND. J. Global Legal Stud. 19 (2008).

2. This is not to exclude, of course, the other potential sources of information which a juridical body might consult, such as the writings of highly qualified jurists. See Statute of the Int'l Ct. of Justice chap. II art. 38, June 26, 1945, 59 Stat. 1031, 33 U.N.T.S. 993; see also Oppenheim's IN TERnational Law 45 (Robert Jennings \& Arthur Watts eds., 9th ed. 1992) (stating that Article 38 should not be interpreted as the eternal and exhaustive list of international law's sources). It may be of some utility to distinguish between the formation of CIL and the making of CIL. CIL formation refers to the organic process by which custom congeals into a preemptory norm and CIL making refers to a more precise moment-that being the moment at which a juridical body assesses existing practice and opinio juris in respect to a particular norm and, using such information, declares a norm to have become law as a matter of custom.

3. See, e.g., Edwin W. Tucker, Has the Individual Become the Subject of International Law?, 34 U. Cin. L. Rev. 341 (1965); Sean MacBride, Conference of European Jurists on "The Individual and the State," 3 IN T'L Law. 603 (1969) (each arguing that the individual has become a subject of international law).

4. See generally Ochoa, International Law Formation, supra note 1; Ochoa, Towards a Cosmopolitan Vision, supra note 1.

5. I should note at the outset that this connection is one for which I have scoured existing literatures in a variety of disciplines and, at least as of this writing, have not found satisfactorily explored. Because this essay will only begin to treat this question with the attention it deserves, it is 
essay is to provide some initial thoughts regarding the relationship between participatory democracy and participatory law formation.

\section{Participatory Democracy ${ }^{6}$}

The origin of the theory of participatory democracy is often credited to JeanJacques Rousseau who presented the argument that authority over a people can only be legitimate if it leaves those who it governs as free as they were prior to their submitting to that authority. Participatory democracy grants individuals the ability to participate in "making" the laws they must obey.?

In modern democratic theory, Carole Pateman is often cited for reviving and developing the idea of participatory democracy. ${ }^{8}$ Although the orientation of Pateman's work focused on the workplace as the location for participatory "political" decision making, the re-introduction of participatory democratic theory has influenced not just political theory, but also ideas such as cosmopolitan democracy ${ }^{9}$ and theories of e-democracy. ${ }^{10}$

An orientation toward a robust model of positive liberty is at the core of any theory of participatory democracy and also of any theory of participatory law formation, including CIL formation. This orientation, however, is not a radical one. Rather, debates over the merits of positive versus negative liberty in the national context, are among the most enduring in modern political life. ${ }^{.1}$ At the international

my great hope that I have in fact missed an existing scholarly discourse on this topic and that it will be brought to my attention.

6. This essay will use the term "participatory democracy." Others have used "direct democracy," "pure democracy," and "strong democracy" to theorize and describe largely similar concepts.

7. Jean-Jacques Roussead, The Social Contract (G. D. H. Cole trans., 1762), hittp:/www .constitution.org/jir/socon_01.htm\#008 (last visited Feb. 20, 2008). Though Rousseau is often credited with the theory of participatory democracy, the Athenian model was one of direct democracy. Montesquieu and Machiavelli are also cited as having elements of this theory in their writings. Political Philosophy: Theories, Thinkers, Concepts 358 (Seymour Martin Lipset ed., 2001).

8. See Benjamin Barber, Strong Democracy 7-8 (1984). See generally Carole Pateman, Participation and Democratic Theory (1970).

9. See Daniele Archibugi, Cosmopolitan Democracy and Its Critics, 10 Eur. J. INT'L ReL. 437 (2004). Archibugi defines cosmopolitan democracy as an effort "to globalize democracy while, at the same time, democratizing globalization." Id. at 438.

10. See Yanis Varoufakis, Accessz2Democracy, E’Democracy in Context: Putting the Demos Back into Democracy?, http://www.access2democracy.org/a2d/content/en/context/EdemocracyinContextbyVaroufakis.pdf (presenting an accessible entry into e-democracy theory).

11. For a well-synthesized presentation of the positive vs. negative liberty debate or the conflict between revisionist and participatory democratic theorists, see Political Philosophy, supra note 7 , at $195-205$. 
level, an orientation toward positive liberty and participatory democracy mirrors that adopted by the United Nations and the Council of Europe, both of which have institutionalized avenues for direct participation from non-state actors. ${ }^{12}$

\section{Modern Participatory Law Formation}

In recent years, there has been a virtual explosion of literature that points toward markedly private or privatizing modes of international governance and law formation that arise from the activities and agreements of private actors, rather than from state-controlled lawmaking in the form of treaty or custom. Business entities, non-governmental organizations (NGOs), broader civil society, and individuals have each been cited as the points of origin of norms, soft law, regulation, or governance dealing with international matters.

Precise examples are discussed in other contributions to this symposium. The privately developed ordering rules formed by the finance sector which Janet Koven Levit discusses are one type of example. ${ }^{13}$ Corporate codes of conduct developed by NGOs and larger civil society activity resulting in projects such as the anti-sweatshop movement that forms the backdrop of Purnima Bose's research are parts of another example. ${ }^{14}$ Providing evidence that the involvement in law-affecting projects is not only an activity of the global elite, Boaventura de Sousa Santos and César Rodríguez-Garavito have elsewhere collected a series of essays documenting what they term subaltern cosmopolitan legality. Santos and Rodríguez-Garavito catalog instances in which the most disenfranchised and dispossessed people in the world are participating in the making and un-making of law. ${ }^{15}$ While I recognize the points of criticism that might be made of grouping the participation in law formation activity on the part of the finance sector together with law formation activity on the part of the citizens of Porto Alegre or the women of Tanzania, there are also

12. Economic and Social Council (ECOSOC), Res. 1996/31, If 19, U.N. Doc. E/1996/31 (July 25, 1996), available at http://www.globalpolicy.org/ngos/docs96/e1996-31.htm; Council of Europe, Committee of Ministers, Resolution Res(2003)8, Nov. 19,2003, preamble, available at http://www .coe.int/t/e/ngo/public/participatory_status/resolution_\%282003\%298/Resolution_2003_8 .asp\#TopOfPage.

13. Janet K. Levit, Bottom-Up Lawmaking: The Private Origins of Transnational Law, 15 Inv. J. Global Legal Stud. 49 (2008). David Snyder has also examined law that is formed by non-state actors in the commercial context. See Private Law, 64 Oнı ST. L.J. 371 (2003).

14. Purnima Bose, From Agitation to Institutionalization: The Student Anti-Sweatshop Movement in the New Millennium 15 Ind. J. Global Legal Stud. 213 (2008).

15. See generally Law and Globalization from Below 6 (Boaventura de Sousa Santos \& César A. Rodríguez-Garavito eds., 2005). 
important similarities; primarily, an active and direct engagement with rule and law formation and lawmaking, often outside of existing state-oriented structures.

The object of this essay, however, is not to summarize or re-describe instances of participatory law formation that others have encountered. Rather, the objective is to explore what relationship these instances have on our concept of state-bounded, representative democracy and whether theories of participatory democracy are useful in explaining or justifying direct engagement in the law formation process.

\section{Isolated Fields of Participation or Important Relationships?}

\section{A. The Deficiencies of Representative Democracy in the International Setting}

Under a system of representative democracy, citizen participation is limited to voting for the individuals who will (at least in the idealized version) represent their interests in all matters of government, including lawmaking. ${ }^{16}$ Representative democracy does not require representatives to acquire direct authorization from the people who they represent before making each political decision to act. They do not act as the people's proxies. Rather, they are endowed with the power to act as they believe will best serve their constituents, as they make, reform, and un-make law. ${ }^{17}$

In the realm of international law, the citizens of any given state are deemed to be represented by their state's participation in the international institutions that promulgate treaties and set policies, regardless of whether that state is democratic internally. ${ }^{18}$ This transposition of representative democracy, which hitherto had operated in local and national systems with various degrees of success, onto governance at the international level has not been entirely successful.

The observation that this form of representation in international lawmaking has created a democratic deficit has been made by others. ${ }^{19} \mathrm{~A}$ subset of these critiques points to the lack of actual democratic participation by, and meaningful

16. See, e.g., R.F. Ankersmit, Political Representation 91-132 (2002).

17. For a concise presentation of representative democracy, see Suzanne Dovi, Political Representation, Stanford Encyclopedia of Philosophy, Jan 2, 2006, http://plato.stanford.edu/entries/ political-representation/.

18. Being a democratic country has not been a prerequisite to entry for countries wishing to become members of the United Nations. Myanmar/Burma serves as just one of many examples of states that are non-democratic but are, nonetheless, members of the United Nations. The author recognizes, of course, that the people of a non-democratic state would not be better represented if their state was ineligible for United Nations membership.

19. See, e.g., Robert Nye, Globalization's Democratic Deficit, How to Make International Institutions More Accountable, 80 ForeIGN AfF. 2 (2001), available at http://fullaccess.foreignaffairs 
representation of, individual citizens in the laws made and policies set by international institutions as symptomatic of the legitimacy crisis these institutions currently face..$^{20}$

\section{B. The Emergence of Participatory Law Formation in Concert with Cosmopolitanism}

From my perspective, the most insightful observations regarding this democratic deficit move beyond the necessary criticisms of current international institutional models and observe instances of private entities engaged in international law formation, marking participatory law formation as the externalized effect of a failing experiment in transposing representative democracy onto international institutions. ${ }^{21}$

Fuller explorations of participatory law formation are made in the context of theories and descriptions of a morally-based cosmopolitan identity and cosmopolitan citizenship which, in its moderate forms, observes the imaginations and palpable activities of individuals reaching across national boundaries for political identification and suggests that these activities are evidence of an emerging sense that people are becoming citizens of the world. Linda Bosniak ${ }^{22}$ and Anthony Appiah $^{23}$ provide two examples of this line of thought.

Distinct-at least conceptually distinct in some respects-from cosmopolitan citizenship lies the attendant and connected idea of globalized or cosmopolitan democracy that garnered significant attention from the end of the Cold War through the 1990s and continues to spark the political and legal imagination. Among the greatest proponents of the idea of cosmopolitan democracy are David Held and Daniele Archibugi who have advocated the global spread of democracy as well as democratized globalization. ${ }^{24}$ Cosmopolitan democracy takes upon itself the project of furthering democracy within national borders and also between states in the

.org/20010701 facomment4989/joseph-s-nye-jr/globalization-s-democratic-deficit-how-to-makeinternational-institutions-more-accountable.html.

20. See Mathias Kumm, The Legitimacy of International Law: A Constitutionalist Framework of Analysis, 15 Eur. J. INT'L L. 907-31 (2004); Thomas M. Franck, Democracy, Legitimacy and the Rule of Law: Linkages, 7-11 (N.Y.U. L. Sch. Pub. L. \& Legal Theory Working Paper Series, Paper No. 2, 1999), available at http://ssrn.com/abstract $=201054$.

21. See, e.g., Archibugi, supra note 9, at 441-53.

22. Linda Bosniak, Citizenship Denationalized, 7 Ind. J. Global Legal Stud. 447 (2000) (articulating a theory of denationalized citizenship).

23. Kwame Anthony Appiah, The Ethics of Identity 213-72 (2005).

24. Archibugi, supra note 9, at 438. 
form of international cooperation. But, most importantly for the purposes of this paper, cosmopolitan democracy also seeks to further democracy beyond states. ${ }^{25}$

In a 2004 article, Cosmopolitan Democracy and its Critics, Archibugi reviews the state of the play in the discourse over cosmopolitan democracy. In it, he describes in some detail what he calls the "Seven Assumptions for Cosmopolitan Democracy." ${ }^{26}$ This essay will focus on just three of these assumptions, given their importance to the questions explored herein:

- Globalization erodes states' political autonomy and thereby curtails the efficacy of state-based democracy.

- The stakeholders' communities in a relevant and growing number of specific issues do not necessarily coincide with states' territorial borders.

- Globalization engenders new social movements engaged with issues that affect other individuals and communities, even when these are geographically and culturally very distant from their own political community.

Each will be briefly treated in turn.

The assumption that globalization erodes states' political autonomy is not at all new or surprising to any scholar of international law. It has long been noted that it is increasingly rare to conceive of international issues in which states are autonomous actors enjoying their sovereign right to bear few responsibilities to other states or to private actors. ${ }^{27}$ This raises questions about the grounds on which political decisions can be deliberated by democratic means. If states no longer hold the sovereign autonomy they may have once enjoyed, who should be included in any international democratic deliberative process and how should that process unfold? ${ }^{28}$

A second assumption-that stakeholders' communities in many specific issues do not necessarily coincide with states' territorial borders—is similarly unsurprising

25. Id.

26. Id. at 439. The full list of seven is as follows: "[1] [d]emocracy is to be conceptualized as a process, rather than as a set of norms and procedures; [2] [a] feuding system of states hampers democracy within states; [3] [d] emocracy within states favours peace, but does not necessarily produce a virtuous foreign policy; [4] [g]lobal democracy is not just the achievement of democracy within each state; [5] Ig]lobalization erodes states' political autonomy and thereby curtails the efficacy of state-based democracy; [6] [t] he stakeholders' communities in a relevant and growing number of specific issues do not necessarily coincide with states' territorial borders; [7] [g]lobalization engenders new social movements engaged with issues that affect other individuals and communities, even when these are geographically and culturally very distant from their own political community." Id.

27. Id. at 443.

28. See id. at 439-40. 
and is also fairly indisputable. Environmental protection and global warming concerns are quintessential global problems for which stakeholder communities clearly are not congruent with state territorial borders, but there are many others. The emergence of global feminism ${ }^{29}$ serves as another such example.

Admittedly, environmental issues, global feminism, or any number of similar non-territorially-delineated issues and stakeholder communities, possess domestic qualities. However, the salient characteristic of each in relation to the other is that none of them can be adequately addressed under a purely domestic framework, and all of them look beyond the state and towards transnational sources of inspiration, support, and political action.

The final assumption described by Archibugi is that globalization engenders new social movements and global participation. The assertion here is that, increasingly, one's sense of self is global instead of national or at least global in addition to national. This results in the emergence and success of international NGOs and global movements. ${ }^{30}$

This multilayered notion of one's political self presents real problems for any claim to legitimacy made by a predominant system of state-centered representative democracy. One question among many might be how a representative to a state or national assembly, who has been voted into power by a community that is only geographically affiliated, can claim full legitimacy to act on issues that either extend outside the scope of that geographic realm or whose solutions are most likely to emerge through expansive conceptions of political activity that extend beyond that geographic realm.

Cosmopolitan democratic theory and cosmopolitan democratic action are still in their infancy. ${ }^{31}$ This seems to result in a sense among both proponents and critics that the possibility of cosmopolitan democracy is as fragile today as it has been at any other point in history. Modern cosmopolitan theorists, hoping to strengthen the theoretical foundation of the idea, argue that:

[m] any of the standard assumptions of received democratic theory, and in particular the idea that a distinct and autonomous political

29. See Global Feminism (Myra Marx \& Aili Mari Tripp eds., 2006).

30. Archibugi, supra note 9, at 445. In making the point that individuals find themselves identifying in ways that are non-territorially-defined, Archibugi cites a survey conducted in 2000 on global governance and cosmopolitan citizenship which "found that $15 \%$ [of people] already claim that their principal identity is regional/global, against $38 \%$ who claim it is national, and $47 \%$ who claim it is local." Id. at 444 .

31. Id. at 465 . 
community can be singled out, do not apply any longer to the contemporary world.... Once it is accepted that the boundaries of political communities are no longer exclusively associated with territorial states, the problem acquires a growing relevance. ${ }^{32}$

And, so, globalization scholars from all walks of academia are called to rethink democratic theory, institutions, and process.

\section{Participatory Law Formation: Definitions and Utility}

I should note here that private or participatory law formation can be, and may likely be, noted as non-transparent, non-accountable, and non-democratic. Surely, from the perspective of representative democratic theory, this type of law formation may be perceived in these ways. But I would like to suggest that any dichotomy which sets state-made law and democracy on one side and private law formation and democratic deficits on the other is going to be overly simple. It will be a far more fruitful enterprise to think about this false dichotomy in more nuanced ways. In particular, I would like to focus on the ways that participatory law formation might be seen to further democracy rather than to debilitate it.

The problem in thinking clearly about what aspects of private law formation further democracy is that there is no rubric, no set of characteristics or rules, that applies easily or whose characteristics or analytical tools are well defined for this project. Within political theory, and even more so within legal theory, the vast majority of the literature on participatory and direct democracy contemplates the direct participation by individuals as occurring entirely within a local or national system.

It has only been since the 1970 s that political science and political philosophy have turned an eye toward the possibilities and difficulties posed by comprehensive, as well as pluralistic, models of participatory democracy. ${ }^{33}$ The literature on cosmopolitan democracy and global citizenship has emerged even more recently and has fueled the imagination and conversation surrounding participatory democracy. ${ }^{34}$

Within legal scholarship, the conversation regarding participatory democracy is even less developed. ${ }^{35}$ Even the few legal scholars who study participatory democ-

32. Id.

33. See Pateman, supra note 8; Barber, supra note 8.

34. See Cosmopolitan Democracy (Daniele Archibugi \& David Held eds., 1995) (presenting a series of essays on issues related to cosmopolitan democracy).

35. A LexisNexis search for "participatory democracy" turned up over 1300 articles that employ that term at least once. However, most used the term without definition and the concept was not a 
racy are not engaged in a study of how a collective group of individuals might come to govern themselves. Rather, such scholars are likely to be focusing their attentions on the ability of citizens in some states to make laws through private initiatives. ${ }^{36}$

To the extent that U.S. courts have directly discussed the validity of individual participation in lawmaking and its relationship to democracy, they have done so in the context of these citizen initiatives. ${ }^{37}$ This kind of participatory lawmaking is distinct from what I have in mind in this essay and in my deeper work on individuals' participation in CIL formation.

The impetuses to lawmaking in private citizen initiatives are private citizens and, in this way, private citizen initiatives are similar to a "bottom-up" approach to lawmaking. They are also similar in that, eventually, participatory democratic processes of all types may result in lawmaking that, by definition, would be incorporated by the state. However, there are clearly distinctions to be drawn between private citizen initiatives and the participatory democratic processes that might lead to custom formation and, thereby, to lawmaking. First, the initiative process is established in state constitutions, and the procedures that citizens must follow in pursuing a private citizen initiative are established in state statutes. ${ }^{38}$ Private citizen

central focus of the work. By contrast, a LexisNexis search for articles with "participatory democracy" in the title turned up only nine hits.

36. For example, Beth Garrett, formerly on the University of Chicago School of Law faculty, refers to herself as one of the few legal academics in this country who study direct or participatory democracy. She studies the ability of citizens in about half of the states of this country to make laws through private citizen initiatives. California provides one familiar example of lawmaking through private initiatives. See Jane S. Schacter, The Pursuit of "Popular Intent": Interpretive Dilemmas in Direct Democracy, 105 YALE L. J. 107 (1995) (focusing on statutory construction and direct legislation). This essay acknowledges that private citizen initiatives are a step toward participatory democracy. Indeed, in jurisdictions that do not provide for private citizen initiatives, there can be significant resistance to the idea. Official Tennessee documents say: "the use of referenda as a method of gauging the electorate's view of particular issues is totally foreign to the representative system of government in Tennessee.” Off. of the Att'y Gen. No. 83-492, Nov. 17, 1983. Similarly, case law establishes that the legislative power is "the authority to make, order, and repeal" laws. Richardson v. Young, 125 S.W. 644, 668 (Tenn. 1909). Another court has held that a power that is "purely legislative" cannot be delegated. Dep't of Pub. Welfare v. Nat'l Help "U" Association, 270 S.W.2d 337 (Tenn. 1954).

37. See Julian N. Eule, Judicial Review of Direct Democracy, 99 Y ALE L.J. 107 (1995) (discussing statutory approaches to direct legislation); Note, Judicial Approaches to Direct Democracy, 118 Harv. L. Rev. 2748 (2005).

38. Among the states that provide for private citizen initiatives, there is a good deal of variety in the procedures citizens must follow. See Phillip L. Dubois \& Floyd Feeney, Lawmaking By Initiative: Issues Options and Comparisons 27-45 (1988). 
initiatives are state-designed and regulated, leaving states with a good deal of control over how and when private citizens may engage in this participatory activity. ${ }^{39}$

In contrast, the types of private law formation I am addressing lie outside of state-sanctioned processes. The questions I am fundamentally trying to address are in respect to whether the state can be taken out of the equation at any stage leading up to law formation or lawmaking without taking democracy out of the equation. There are ample examples of transnational action networks, ${ }^{40}$ Internetbased political action, ${ }^{41}$ and global projects from all points on the political leftright spectrum ${ }^{42}$ that have gained significant attention, altered policy, and made soft law that tends toward hardening.

Through these mechanisms, the interests of various communities that could not be represented adequately and attention to problems that could not be comprehensively and justly handled within state-based democratic systems are provided with a political opening that would not be available through a purely state-based, representative democratic model. In addition, the quality of political participation in private law formation projects, in at least some respects, may be higher than what is possible through representative democratic processes alone, in which citizen participation is largely confined to a voting right.

Consider, for example, the quality of political participation available to an advocate of corporate social responsibility in the classic representative democracy, in comparison to the quality of participation in a system that allows for transnational discourse and norm-formation related to corporate social responsibility. In the representative democracy model, people can vote for and perhaps write to their representatives in the hope that their representative will prioritize and address their concerns. In the participatory law formation scenario, on the other

39. This includes, of course, the potential of repealing statutes which permit private citizen initiatives.

40. For an empirical analysis of transnational action networks in the environmental context, see, for example, Robert Rohrschneider \& Russell Dalton, A Global Network? Transnational Cooperation Among Environmental Groups, 64 J. PoL. 510 (2002).

41. The political action campaigns carried out by organizations such as MoveOn.org are examples of this type of activity. See, e.g., MoveOn.org, http://www.moveon.org/about.html (last visited Feb. 21, 2008) ("The MoveOn family of organizations brings real Americans back into the political process. With over 3.3 million members across America-from carpenters to stay-at-home moms to business leaders-we work together to realize the progressive promise of our country. MoveOn is a service-a way for busy but concerned citizens to find their political voice in a system dominated by big money and big media.").

42. Examples might include the international environmental rights or human rights movement or a global right to life movement. 
hand, there is a political opening for individuals to engage one another directly and through organizations. The resulting discourse can and has contributed meaningfully to the development of norms and laws in an area that was not drawing the attention of elected legislative bodies. The United Nations Norms on the Responsibilities of Transnational Corporations and Other Business Enterprises with Regard to Human Rights provides one such example in the corporate social responsibility area. ${ }^{43}$ Private codes of conduct, adopted by individual corporations are similarly the result of this deliberative political engagement.

However, just as there seems to be reason to reject the assumption that this type of participatory law formation is undemocratic, it also seems necessary to resist the temptation to make claims that it is necessarily democracy-enhancing. There are potential problems with participatory law formation. For example, it is potentially a very elite-centered activity. ${ }^{44}$ Unlike state-centered lawmaking, which typically results in public disclosure of the laws and policies in place as well as the process by which they were adopted, participatory law formation is often private or even secretive, making it difficult to discover and understand..$^{45}$

In addition, our common understanding of democracy as including some form of majoritarian rule is offended by participatory law formation, in which interest groups comprised of highly interested individuals or organizations might set policy or make rules affecting many who had no role in the rule formation process ${ }^{46} \mathrm{As}$ a relevant aside, some cosmopolitan democracy theorists have alluded to rethinking the "obsession" with majoritarian rule such that interested parties-stakeholders in a particular issue-might carry more import in any given decision than the citizenry at large. ${ }^{47}$ But such a position begs reactions to ensure that any such weighting would not discount communities that only come to recognize their interest in a given issue well after a system of rules has been established.

The exercise of identifying and analyzing the ways that participatory law formation can weaken democracy is very important. But no amount of identification

43. ECOSOC, Sub-Comm'n on Promotion \& Protection of Human Rights, Norms on the Responsibilities of Transnational Corporations and Other Business Enterprises with Regard to Human Rights, U.N. Doc. E/CN.4/Sub.2/2003/12/Rev.2 (Aug. 26, 2003), available at http://www.unhchr .ch/huridocda/huridoca.nsf/(Symbol)/E.CN.4.Sub.2.2003.12.Rev.2.En.

44. Snyder, supra note 13 , at 430-32.

45. See Lisa Bernstein, Opting Out of the Legal System: Extralegal Contractual Relations in the Diamond Industry, 21 J. Legal Stud. 115 (1992); Snyder, supra note 13, at 430-32.

46. Snyder, supra note 13, at 433.

47. Archibugi, supra note 9 , at 462-63. 
and analysis will impede the participatory law formation that is already occurring in various sectors.

If this activity is inevitable given surrounding circumstances-or even just on the grounds that it is extant-we are left asking what we can do to encourage, direct, or regulate participatory law formation projects in directions that promote democratic participation and, perhaps, participatory democracy. To do this, it is essential to re-acquaint ourselves with characteristics of democracy that extend beyond mere rule of the people by the people. These characteristics come in two essential forms: rights and infrastructure.

There are certain rights that are regularly cited as essential to a full democracy. These include the requirements that all individuals enjoy full liberty of action, freedom to participate, and equality vis-à-vis one another, as well as protection and promotion of the full range of civic freedoms. Participatory law formation that includes the protection of these civil and political rights may well be able to describe itself as part of participatory democracy.

In addition, there are infrastructural requirements for a full and well functioning democracy. Transparency in the law formation process, including disclosure of the identity of participants, the source of funds used in the law formation process, and the political and institutional mechanisms and procedures by which rules, norms, and soft laws are developed, would help ensure accountability of involved actors as well as improve accessibility for minority views, latecomers, and non-involved actors. Moreover, the application of existing hard law prohibiting corruption and other illegal activity would help create a sense that private parties who have become participatory lawmakers would be bound by the rule of law as they engage in law formation.

Finally, there must be some system for public review, approval, and consent of the law promulgated by private parties. This is where Held's and Archibugi's calls for concrete proposals for means by which the cosmopolitan democratic project can be implemented are particularly important and difficult. As Janet Koven Levit has already suggested, judicial implementation of privately made rules alrcady occurs. ${ }^{48}$ Further research is necessary to discover how often judges scrutinize the process by which the privately made rules that courts enforce as law were made. For example, are judges simply using the Uniform Customs and Practice 500 (UCP 500) and other trade finance rules set by private associations as if they were inscrutable, rather than analyzing and questioning the validity of the law formation process? Existing literature suggests that even in the case of private citizen initiatives, judicial review

48. Levit, supra note 13 , at 59. 
rarely has made note of the special character by which such laws are made, even when the substance of the law has been drawn into question. ${ }^{49}$

In the absence of such scrutiny, it is not surprising that in assessing participatory law formation processes and projects against the substantive rights and infrastructural design requirements which are normally associated with democracy, critics of participatory law formation would come to the conclusion that this activity is inherently non-democratic. This position, however, is at least somewhat fatalistic, given the growing body of evidence that participatory law formation has become an inherent characteristic of globalization that is not likely to diminish.

Rather than denounce or extol participatory law formation, it seems the more relevant and useful contribution is to engage in the constructive and creative project of thinking about how local, state, international, and, indeed, global governance, can accommodate the tendency toward participatory law formation and ensure that it furthers democratic ends such as political enfranchisement and the promotion of human dignity. The age of globalization requires us to think in nuanced ways about sovereignty, governance, political activity, and individual identity-all of which are best now conceived as multilayered. Similarly, I posit that the best models of democracy may also need to become multilayered, accommodating both representative and participatory frameworks. 